\title{
Analisis Tingkat Pengetahuan Mahasiswa Semester 4 Pendidikan Fisika Universitas Jember mengenai Pembangkit Listrik Tenaga Pikohidro
}

\author{
Alfrida Diftia Vestnanda ${ }^{1^{*}}$, Sudarti ${ }^{1}$ \\ ${ }^{1}$ Program Studi Fisika Fisika, FKIP Universitas Jember, \\ Jember 68121, Indonesia \\ *e-mail:190210102109@mail.unej.ac.id
}

Received: 01 Januari 2021. Accepted: 30 Januari 2021. Published: Februari 2021

\begin{abstract}
Abstrak
Pembangkit listrik tenaga pikohidro masih sangat jarang diterapkan di kota Jember, padahal beberapa daerah Jember memiliki arus sungai yang baik dan berpotensi sebagai pembangkit listrik tenaga pikohidro. Penelitian ini memiliki tujuan untuk mengetahui tingkat pengetahuan mahasiswa semester 4 Pendidikan Fisika Universitas Jember mengenai Pembangkit Listrik Tenaga Pikohidro. Penelitian ini menggunakan metode deskriptif dengan instrumen berupa angket digital (google form) yang disebar ke mahasiswa. Sumber data diperoleh dari angket berupa 1 soal isian singkat dan 5 soal pilihan ganda. Hasil jawaban dari angket dianalisis untuk mengetahui pengetahuan mahasiswa semester 4 Pendidikan Fisika Universitas Jember mengenai pembangkit listrik tenaga pikohidro. Hasil analisis menunjukkan 78\% mahasiswa mengetahui nama dan bentuknya. Sedangkan pengetahuan tentang pikohidro yang menjawab benar sebanyak $72 \%$. Masih ada beberapa mahasiswa yang tidak mengetahui karena tekhnologi ini masih jarang digunakan terutama di Kota Jember.
\end{abstract}

Kata Kunci: pikohidro, pembangkit listrik, teknologi alternatif

\section{Analysis of The Knowledge Level of Students at 4th Semester of Physics Education in University of Jember Regarding Picohydro Power Plants}

\begin{abstract}
Pico-hydro power plants are still very rarely applied in the city of Jember, even though some areas of Jember have good river currents and have the potential to become pico-hydro power plants. This study aims to determine the knowledge level of the students of 4th semester of physics education in University of Jember regarding the Pycohydro Power Plant. This research uses a descriptive method with instruments in the form of a digital questionnaire (google form) distributed to students. The data source is obtained from a questionnaire in the form of 1 short questionnaire and 5 questions multiple choice The results of the answers from the questionnaire were analyzed to determine the knowledge of the Students at $4^{\text {th }}$ semester of Physics Education in University of Jember regarding pycohydro power plants. The results of the analysis showed that $78 \%$ of students knew the name and shape, while $72 \%$ of the students having correct answer. There are still some students who don't know this technology because of rarely used, especially in the city of Jember
\end{abstract}

Keywords: picohydro, power generation, alternative technology

\section{PENDAHULUAN}

Fisika lingkungan adalah ilmu yang mempelajari fisika dan matematika yang berkaitan dengan konsep teori lingkungan, termasuk dampak sistem ekologi dan pencemaran yang disebabkan oleh tindakan alam dan ulah manusia terhadap keseimbangan lingkungan. Fisika lingkungan juga adalah salah satu mata kuliah wajib yang ada di pendidikan fisika Universitas Jember. Mata kuliah ini memiliki macam - macam sub tema, salah satunya yaitu energi alternatif dan 
energi terbarukan. Sumber daya akan selalu tersedia dan tidak akan merusak lingkungan. Berasal dari sejumlah besar unsur alam yang tersedia di bumi, seperti matahari, angin, sungai, dan tumbuhan merupakan asal dari energi terbarukan. Energi terbarukan adalah energi yang dihasilkan dari sumber daya alam (seperti matahari, angin, dan air) dan dapat dibangkitkan berulang kali. Energi terbarukan merupakan sumber energi paling bersih yang tersedia di planet ini (sanjaya, 2016). Badan Energi Internasional (IEA) mendefinisikan energi terbarukan sebagai energi yang berasal dari proses alami yang diisi ulang pada tingkat yang lebih cepat daripada yang dikonsumsi dan menyebutkan tenaga surya, angin, panas bumi, hidro, dan biomassa sebagai contoh energi terbarukan (Harjanne, 2019). Semua sumber energi yang tersedia yang dirancang untuk menggantikan bahan bakar konvensional merupakan istilah dari energi alternatif. Mengurangi penggunaan bahan bakar hidrokarbon yang menyebabkan kerusakan lingkungan akibat emisi karbondioksida yang tinggi, yang berkontribusi besar terhadap pemanasan global merupakan istilah umumnya.

Pengembangan dan penelitian sumber energi alternatif masih terus dilakukan, terutama pada peralatan atau mesin modern saat ini, seperti pompa air tenaga surya. Penggunaan energi alternatif memang dapat menghabiskan sumber daya dan investasi yang besar, dalam jangka panjang manfaatnya akan terlihat jelas. Salah satu manfaat energi alternatif adalah dapat mengurangi dampak energi fosil. Bahan bakar fosil membutuhkan waktu jutaan tahun untuk terbentuk dan cadangan yang diketahui dapat terus terkuras jauh lebih cepat daripada pembuatan bahan bakar fosil baru. Pada saat yang sama, bahan bakar fosil mengeluarkan gas rumah kaca, yang akan mempercepat perubahan iklim seperti pemanasan global sehingga membahayakan lingkungan tempat orang bergantung. Oleh karena itu, dalam beberapa tahun terakhir, energi terbarukan telah menarik banyak perhatian di seluruh dunia. Energi terbarukan mengacu pada energi yang dapat didaur ulang di alam, seperti energi matahari, tenaga angin, energi pasang surut, dan energi panas bumi (Wang, 2019).

Perkembangan ekonomi di era globalisasi telah berdampak pada peningkatan konsumsi energi di berbagai sektor kehidupan. Badan Energi Dunia (IEA) melaporkan pada tahun 2018 bahwa permintaan energi dunia mengalami peningkatan sebesar 2,3\% dibandingkan tahun sebelumnya, dan masih bergantung pada sumber energi fosil seperti minyak bumi, gas alam dan batu bara sebesar $81 \%$. Ketidakseimbangan antara penggunaan energi yang berlebihan dan produksi yang berkelanjutan telah menyebabkan krisis energi dan harga-harga meningkat (Maulina, 2020). Permintaan energi meningkat dengan cepat dan, karenanya, penting untuk memperkenalkan proses untuk memenuhi populasi dunia dan menghindari krisis energi. Pada tingkat konsumsi energi saat ini, permintaan diperkirakan akan meningkat $65 \%$ pada tahun 2030, dengan menggunakan tahun 2004 sebagai tahun dasar. Saat ini, sebagian besar energi yang digunakan secara global dihasilkan dari sumber yang tidak terbarukan seperti pembangkit listrik tenaga batu bara yang menjadi persyaratan pembangkit listrik. Ini dikenal untuk masalah Gas Rumah Kaca (CO2, NOx, dan SOx) menyebabkan emisi serta berkontribusi terhadap pemanasan global (Qazi, 2019).

Salah satu komponen terpenting untuk mendukung pembangunan negara ialah listrik. Pertambahan jumlah penduduk, peningkatan pembangunan, dan perbaikan taraf hidup telah 
menyebabkan peningkatan laju konsumsi energi listrik oleh pengguna energi untuk tujuan komersial dan sosial, dan pengguna listrik untuk kebutuhan rumah tangga. Akan tetapi, pasokan listrik terbatas dan sumber daya yang tersedia juga terbatas (Usman, 2017).

Permintaan listrik saat ini semakin meningkat, sedangkan kapasitas pembangkit listrik pemerintah dibatasi, yang menyebabkan krisis listrik di manamana. Kondisi medan membuat keadaan semakin pelik, karena biasanya daerah pegunungan bergunung-gunung, dan kemiringan sawah bervariasi dari landai hingga sangat terjal. Oleh karena itu, menurut data Perusahaan Listrik Negara, masih banyak desa terpencil yang belum tersambung listrik. Indonesia masih memiliki 2.500 desa tanpa listrik. Di sisi lain, Indonesia memiliki berbagai sumber listrik yang tersedia, antara lain tenaga air, panas bumi, batu bara dan uap. Semua sumber energi listrik memiliki kekurangan dan kelebihannya sendiri, baik dari segi ketersediaan bahan baku maupun risiko imbas negatifnya yaitu terhadap biaya investasi dari segi lingkungan. Indonesia adalah negara berupa kepulauan dengan banyak anak sungai mengalir dari puncak gunung, jadi prospeknya banyak Sangat cocok untuk pembangunan Pembangkit Listrik Tenaga Pikro Hidro (PLTPH) (Nakhoda, 2018).

\section{Pembangkit Listrik Picohidro} adalah pembangkit listrik dengan daya maksimal $5000 \mathrm{~W}$, biasanya digunakan di daerah terpencil terutama desa perbukitan. Genset jenis ini banyak digunakan tidak terlalu banyak energi hanya digunakan di beberapa rumah sebagai sumber penerangan. Potensi aliran air di kawasan pemukiman daerah pedesaan memiliki potensi energi yang baik dan dapat menggantikan pembangkit listrik, walaupun pembangkit listrik masih sangat terbatas. (PLTPH) merupakan salah satu teknologi pembangkit listrik yang ramah lingkungan karena memanfaatkan aliran sungai atau air terjun untuk menjadi sumber listrik melalui turbin. Secara teknis, Picohydro punya tiga komponen utama yaitu air (sumber energi), turbin dan generator (sebagai konverter), mengubah energi mekanik menjadi energi listrik. memanfaatkan tinggi terjunnya dan jumlah debit air merupakan prinsip kerjanya (Nakhoda et al, 2018).

Tahapan membuat (PLTPH). Pada langkah pertama, pembangkit listrik tenaga mikro hidro harus dibangun hal pertama yang harus dilakukan adalah membuat mikro-pembangkit listrik tenaga mikro dengan membeli sebuah rotor Kemudian modifikasi generator magnet permanen pada suku cadang sepeda motor lama Kemudian dirangkai menjadi sebuah rotor dengan total 6 (enam) kutub magnet permanen Pemasangan poros. Selanjutnya buat tempat (rumah) genset dengan pipa besi yang lebih besar, dipotong berdiameter 5 dim untuk menyesuaikan panjang dari rotor generator. Rumah (tempat) stator Generator merupakan tempat kawat enamel yang terdiri dari 6 kumparan ditempatkan (6) Sebuah kumparan disesuaikan dengan diameter pipa besi. Sehingga genset tidak mau Pada saat air memercik dari turbin saat berputar, maka harus dirancang untuk ditutup pada sisi depan dan belakang genset, kemudian disegel dengan 3 (tiga) baut panjang. Tahap kedua adalah uji laboratorium untuk mengetahui tujuan dari penentuan unjuk kerja generator magnet permanen sebelum merakit mikro generator dengan turbin mikrohidro dan mengaplikasikannya ke sungai di lokasi rekanan. Tujuannya untuk mengetahui Gunakan perubahan kecepatan (rpm) Tanpa menimbulkan beban, kemudian dilakukan pengujian kembali dengan kecepatan yang sama seperti pada lampu LED. Tahap ketiga, yaitu pembuatan kincir air / turbin pikohidro, bagian 
peralatan melingkar dari sistem pembangkit listrik, fungsinya adalah mengubah energi dalam air menjadi energi rotasi dan putar porosnya Hubungkan ke generator untuk menghasilkan listrik. Tahap keempat merupakan tahap dari perakitan turbin hidrolik dan generator magnet permanen yang diletakkan di atas rangka pipa besi yang didesain portabel, lalu pasang katrol, Pada saat yang sama, vanbelt dipasang untuk menghubungkan generator dan turbin. Tahap kelima, merupakan pemasangan pembangkit listrik tenaga pikohidro ke tempatnya. Tahap keenam yaitu memasang kabel dari PLTPH, memasang control panel ke lokasi rumah mitra, dan memasang lampu LED sesuai kebutuhan rumah mitra (Wahid, 2020).

Dari penjelasan diatas bisa dilihat jika Pembangkit Listrik Tenaga Pycrohydro (PLTPH) sangat dibutuhkan di indonesia khususnya di daerah pedesaan yang masih tidak terjangkau oleh listrik negara. Penggunaan Pembangkit Listrik Tenaga Pycrohydro (PLTPH) juga masih minim diterapkan di indonesia sehingga perlu dikembangakan lagi di indonesia. Pembangkit listrik tenaga pikohidro masih sangat jarang di terapkan di kota Jember, padahal beberapa daerah Jember memiliki arus sungai yang baik dan berpotensi sebagai pembangkit listrik tenaga pikohidro. Keberadaan sungai di kawasan Kabupaten Jember, semua airnya Biasanya dimanfaatkan untuk kepentingan masyarakat khususnya sektor pertanian, Hutan industri dan perkebunan. Luas pelayanan irigasi mencapai 85.530 hektar atau 25.972\% dari luas wilayah Kabupaten Bupati terbentang dari utara Di selatan, ada dataran berbukit (pegunungan) di hulu, Di dataran rendah dari tengah hingga selatan Samudera Hindia.Maka dari itu penting mahasiswa mengetahui pengetahuan tentang pembangkit listrik tenaga pikohidro untuk membantu masyarakat di daerah terpencil yang tidak terjangkau listrik negara.

Berdasarkan rujukan yang ada diatas maka telah dilakuakan penelitian tentang Analisis Tingkat Pengetahuan Mahasiswa Semester 4 Pendidikan Fisika Universitas Jember Mengenai Pembangkit Listrik Tenaga Pikohidro.

\section{BAHAN DAN METODE}

Metode yang digunakan dalam penelitian ini adalah metode deskriptif. Metode deskriptif adalah cara untuk memeriksa status kerumunan saat ini, kategori peristiwa, atau sistem pemikiran, kondisi, objek (Nazir, 1988). Sumber data diperoleh dari angket berupa 1 soal uraian singkat dan 5 soal pilihan ganda yang disebar kepada 54 mahasiswa angkatan 2019 pendidikan fisika, Fakultas Keguruan dan Ilmu Pendidikan Universitas Jember. Alat penelitian berupa pertanyaan yang diajukan oleh peneliti sendiri. Instrumen ini berisi pertanyaan-pertanyaan tentang pengetahuan tentang pembangkit listrik tenaga mikrohidro. Kemudian menganalisis data - data dengan melihat skor benar dan salah yang diperoleh dari jawaban mahasiswa.

\section{HASIL DAN PEMBAHASAN}

Hasil penelitian dan pembahasan diambil dari data angket yang diberikan kepada 54 mahasiswa semester 4 angkatan 2019 Pendidikan Fisika, yang berkaitan dengan penelitian Analisis Tingkat Pengetahuan Mahasiswa Semester 4 Pendidikan Fisika Universitas Jember Mengenai Pembangkit Listrik Tenaga Pikohidro. Berdasarkan data yang diperoleh data sebagai berikut.

Dari soal yang diberikan di angket pertanyaan isian singkat, dapat dilihat hanya 3 siswa yang mengisi pembangkit listrik tenaga pikohidro. Artinya teknologi alternatif ini masih 
kurang akrab di kalangan mahasiswa semester 4 Pendidikan Fisika , Universitas Jember.

Pada soal berikutnya disajikan gambar pembangkit listrik tenaga pikohidro. Sebanyak 88\% mahasiswa semester 4 sudah pernah melihatnya, hal ini dapat dilihat pada diagram dibawah.

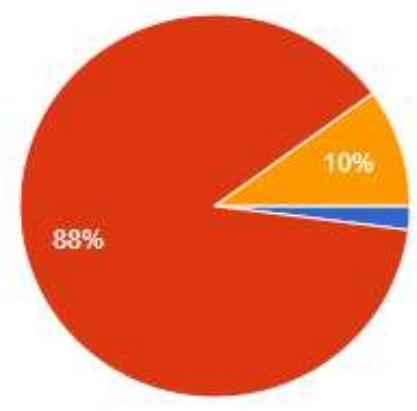

Gambar 1. Diagram Persentase Mahasiswa yang Pernah Melihat tetapi Tidak Mengetahui Nama Pembangkit Listrik Tenaga Pikohidro

Walaupun banyak dari mahasiswa semester 4 pendidikan fisika yang mengetahui gambar dari pembangkit listrik tenaga pikohidro, ternyata dari 88\% mahasiswa tersebut tidak semuanya mengetahui nama dari benda tersebut. Hal ini dapat dilihat dari perolehan data yaitu $78 \%$ mahasiswa yang menjawab benar dan sisanya menjawab salah. Data ini dapat dilihat pada diagram dibawah ini.

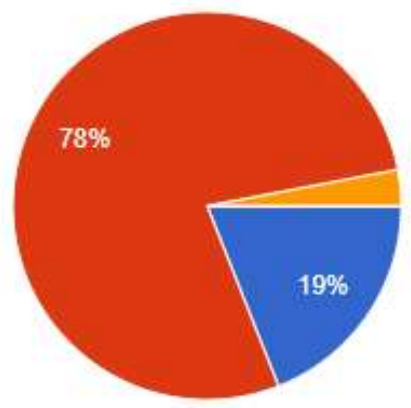

Gambar 2. Diagram Persentase Mahasiswa yang Pernah Melihat dan Mengetahui Nama

Pembangkit Listrik Tenaga Pikohidro

$\begin{array}{ccc}\text { Pertanyaan } & \text { selanjutnya } & \text { yaitu } \\ \text { mengenai sumber energi } & \text { yang }\end{array}$

dibutuhkan oleh pembangkit listrik tenaga pikohidro, sebanyak $98,1 \%$ mahasiswa menjawab benar dan $1,9 \%$ menjawab salah. Data tersebut dapat dilihat dibawah ini.

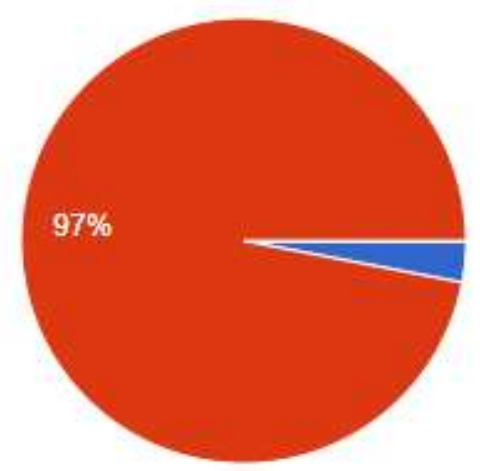

Gambar 3. Diagram Persentase Mahasiswa yang Mengetahui Sumber Energi Pembangkit Listrik Tenaga Pikohidro

Pertanyaan berikutnya yaitu tentang definisi umum pembangkit listrik tenaga pikohidro, dari pertanyaan ini yang menjawab benar hanya $42 \%$ mahasiswa dan 58\% mahasiswa menjawab salah. Diagram dapat dilihat dibawah ini.

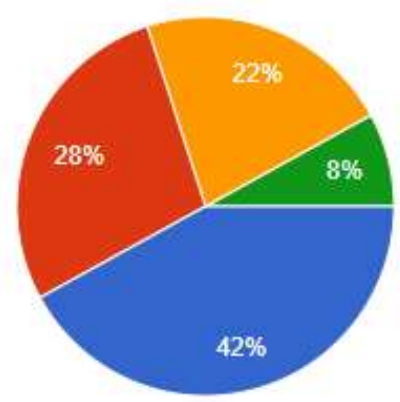

Gambar 4. Diagram Persentase Mahasiswa yang Mengetahui Definisi Umum Pembangkit Listrik Tenaga Pikohidro

Pertanyaan yang terakhir yaitu mengenai prinsip kerja pembangkit listrik tenaga pikohidro. Sebanyak 55\% mahasiswa menjawab benar dan $45 \%$ mahasiswa menjawab salah. Diagramnya dapat dilihat dibawah 


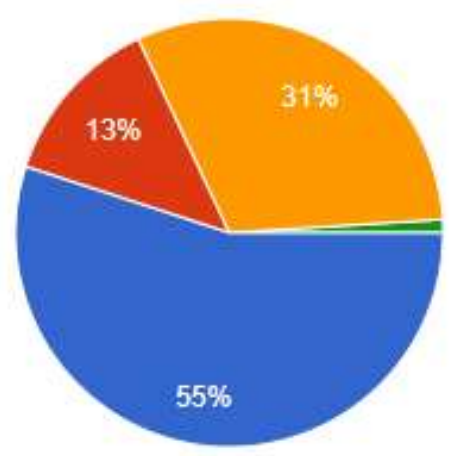

Gambar 5. Diagram Persentase Mahasiswa yang Mengetahui Prinsip Kerja Pembangkit Listrik Tenaga Pikohidro

Dilihat dari data yang sudah dikumpulkan, mahasiswa semester 4 Pendidikan Fisika hampir semua sudah mengenali pembangkit listrik tenaga pikohidro. Akan tetapi melihat jawaban singkat yang diisi oleh mahasiswa, pembangkit listrik tenaga pikohidro masih kurang akrab karena hanya 3 mahasiswa yang menuliskan pembangkit listrik tenaga pikohidro.

Dari pertanyaan sumber energi pikohidro hampir semuanya menjawab benar karena pertanyaan tersebut tergolong mudah dan mahasiswa sudah bisa menebak dengan nama alatnya. Lalu untuk pertanyaan mengenai prinsip kerja sebagian besar mahasiswa sudah menjawab benar artinya sebagian besar mahasiswa mengerti bagaimana cara kerja pembangkit listrik tenaga pikohidro menghasilkan listrik. Lalu untuk pertanyaan lebih mendalam seputar pikohidro hanya kurang lebih yaitu prinsip kerja hanya kurang dari $60 \%$ mahasiswa yang menjawab benar, artinya mahasiswa semester 4 masih kurang mengenali pemabngkit listrik tenaga pikohidro. Hal ini dikarenakan pembangkit listrik tenga pikohidro masih sangat jarang digunakan atau hanya ada di desa terpencil yang tidak mendapat listrik dari pemerintah sehingga beberapa mahasiswa tidak mengerti. Dari hal ini perlunya sosialisasi mengenai pembangkit ini kepada mahasiswa karena banyak tempat di jember yang berpotensi untuk dijadikan pembangkit listrik tenga pikohidro. Mengingat masih banyak desa - desa terpencil di jember, hal ini dapat dijadikan solusi sebagai pengganti listrik.

\section{KESIMPULAN}

Dari analisis yang sudah dijabarkan diatas maka dapat diambil kesimpulan berikut :

1. Mahasiswa semester 4 Pendidikan Fisika, Fakultas Keguruan dan Ilmu Pendidikan, Universitas Jember sudah mengetahui adanya tekhnologi alternatif pembangkit listrik tenaga pikohidro, yaitu sebanyak $78 \%$ mahasiswa mengetahui nama dan bentuknya.

2. Mengenai pengetahuan tentang pembangkit listrik tenaga pikohidro dari data jika di rata - rata sebanyak 72\% mahasiswa menjawab benar. Sehingga sebagian besar mahasiswa Pendidikan Fisika, Fakultas Keguruan dan Ilmu Pendidikan, Universitas Jember banyak yang sudah mengerti dan memahami mengenai pembangkit listrik ini.

\section{DAFTAR PUSTAKA}

Harjanne, A. and Korhonen, J.M. (2019). Abandoning the concept of renewable energy. Energy Policy, 127, 330-340.

Maulina, Wenny, S, Yudi Aris, Purwandari, Endhah. 2020. Biobriket Arang Sekam Padi Sebagai Sumber Energi Terbarukan untuk Aplikasi Pandai Besi. Warta pengabdian,14(4), 222-230.

M. Abdul Wahid and Zulis Erwanto (2020). Perencanaan Dan Penerapan Prototipe Pembangkit 
Listrik Tenaga Piko Hidro (Pltph) Dengan Turbin Tipe Undershoot. Prosiding Seminar Nasional Terapan Riset Inovatif (SENTRINOV). Banyuwangi: Program Studi Teknik Mesin, Politeknik Negeri Banyuwang.

Nakhoda, Y. and Hamid, M. (n.d.).2018. Rancang Bangun Generator Magnet Permanen Fluks Aksial Putaran Rendah untuk Pembangkit Listrik Tenaga Pikohidro. Jurnal ELEKTRIKA,1(2), 1-6.

Nakhoda, Y Ismail, S, Irrine Budi, Soetedjo, Aryuanto. 2018. Penerapan Pembangkit Listrik Tenaga Pikohidro Menggunakan Komponen Bekas Dengan Pemanfaatan Potensi Energi Terbarukan Di Desa Gelang Kecamatan Sumberbaru Kabupaten Jember. Jurnal Aplikasi Dan Inovasi Ipteks, 1(2), 99-109.

Sanjaya, L.A., Budi, A.S. and Astra, I.M. (2016). Pengembangan Alat Peraga Energi Terbarukan. Prosiding Seminar Nasional Fisika . Jakarta: Program Studi Pendidikan Fisika UNJ.
Usman, M., Hasbi, M., Sudia, B., Jurusan, Mesin, T., Teknik, F., Oleo, H., Mesin, J., Halu, U., Jl, O., Mokodompit, Kampus, H., Bumi, T., Andounohu and Kendari (2017). Studi Eksperimen Penggunaan Air Garam Sebagai Sumber Energi Alternatif. Jurnal Mahasiswa Teknik Mesin 2(2),1-6.

Qazi, A., Hussain, F., Rahim, N.ABD., Hardaker, G., Alghazzawi, D., Shaban, K. and Haruna, K. (2019). Towards Sustainable Energy: A Systematic Review of Renewable Energy Sources, Technologies, and Public Opinions. IEEE Access, 7, 63837-63851. 